\title{
D. EUGÊNIO SALES NA ARQUIDIOCESE DE SALVADOR EM TEMPOS DE DITADURA MILITAR
}

\author{
GRIMALDO CARNEIRO ZACHARIADHES (CPDOC-FGV) \\ Professor da Secretaria Municipal de Educação do Rio de Janeiro \\ grimacz@hotmail.com
}

\section{RESUMO}

Este artigo analisará a atuação do arcebispo D. Eugênio de Araújo Sales na arquidiocese de São Salvador, no estado da Bahia, região Nordeste do Brasil, entre os anos de 1964 e 1971. Ele assumiu a arquidiocese em um período de crescimento econômico acelerado no Brasil, e na Bahia em particular, e de recrudescimento político com a instauração e consolidação da Ditadura Militar (1964-1985). Ele foi responsável pela reestruturação da arquidiocese, mas teve conflitos com membros do clero e leigos pela sua relação com o Regime Militar.

Palavras-chave: Dom Eugênio Sales, Igreja Católica, Ditadura Militar, Arquidiocese de Salvador e Bahia

\begin{abstract}
This article will analyze the work of Archbishop Eugenio de Araújo Sales in the archdiocese of São Salvador, in the state of Bahia, Northeastern region of Brazil, between 1964 and 1971. He assumed the archdiocese in a period of accelerated economic growth in Brazil, and in Bahia in particular, and of political upsurge with the establishment and consolidation of the Military Dictatorship (1964-1985). He was responsible for the restructuring of the archdiocese, but had conflicts with members of the clergy and lay people for their relationship with the Military Regime.
\end{abstract}

Keywords: Bishop Eugênio Sales, Catholic Church, Military Dictatorship, Archdiocese of Salvador and Bahia 


\title{
D. EUGÊNIO SALES NA ARQUIDIOCESE DE SALVADOR EM TEMPOS DE DITADURA MILITAR
}

\author{
GRIMALDO CARNEIRO ZACHARIADHES (CPDOC-FGV) \\ Professor da Secretaria Municipal de Educação do Rio de Janeiro \\ grimacz@,hotmail.com
}

\section{Bahia: Desenvolvimento e exclusão}

Até a década de 40 do século XX, a economia baiana estava estagnada. A base econômica do estado ainda se alicerçava em um modelo agroexportador. Entre os produtos de exportação da economia baiana destacavam-se o cacau, o açúcar e o fumo. A dependência em relação aos commodities limitava a possibilidade de expansão para a economia da região, já que era suscetível as inconstantes variações dos preços no mercado internacional. Até a metade do século XX, a Bahia permanecia um dos estados menos urbanizados do país. Salvador, a capital do estado, encontrava nas atividades de comércio e administração pública, seu principal suporte econômico ${ }^{1}$.

As indústrias na Bahia, apesar de certa diversidade, representavam economicamente muito pouco ao estado. A indústria têxtil e fumageira eram insuficientes, sendo um apêndice do modelo primário-exportador. A participação da Bahia no produto industrial brasileiro correspondia a 1,3\% do país em 1940. Problemas na má infraestrutura viária, o fraco mercado interno, baixos níveis de escolaridade da população, atraso tecnológico só agravavam a situação: "a economia baiana conheceu, do final do século XIX aos anos 1930-1940, um período de lento crescimento, marcado pelo débil dinamismo ou pela instabilidade de suas atividades agroexportadoras (...) e, ainda, por baixas taxas de expansão urbana e industrial"2.

Durante a década de 50, esse cenário começou a se reverter. O Governo Federal tentando solucionar o problema do atraso do Nordeste brasileiro buscou proporcionar mudanças estruturais à região e o estado da Bahia foi um dos mais beneficiados, recebendo altos investimentos estatais nesse período. O Banco do Nordeste do Brasil (BNB), criado em 1952, apoiava financeiramente este processo de industrialização e a criação da SUDENE, em 1959, expandiu a oferta de financiamentos públicos. A Bahia - especialmente Salvador e cidades circunvizinhas - desenvolveu-se aceleradamente. A conclusão da ligação rodoviária Rio-Bahia (BR-116), em 1949, permitiu o rápido desenvolvimento do comércio interestadual e acelerou o processo de conexão entre a economia regional e o centro industrial do país. A construção da usina hidroelétrica de Paulo Afonso (1954) ampliou a oferta de energia elétrica para o consumo industrial no estado, eliminando um dos principais pontos de estrangulamento da economia regional.

\footnotetext{
1 BRANDÃO, Maria de Azevedo. "A regionalização da grande indústria do Brasil: Recife e Salvador na década de 70”. In: Revista de Economia Política, vol 5, nº4, outubro-dezembro 1985, p.88-90.

2 ALMEIDA, Paulo Henrique de. "A economia de Salvador e a formação de sua Região Metropolitana". In: CARVALHO, Inaiá. PEREIRA, Gilberto Corso. (orgs). Como anda Salvador e sua região metropolitana. 2ed. Salvador: EDUFBA, 2008, p.20)
} 
Um dos mais importantes agentes de desenvolvimento econômico do período no estado foi a Petrobrás, criada em 1953, que se concentrou na exploração e refino do petróleo no Recôncavo baiano. O estado durante décadas foi o principal produtor de petróleo do Brasil. A estatal assumiu e dirigiu a importante refinaria Landulpho Alves (RLAM), em Mataripe, que tinha sido criada ainda em 1950, ampliando a extração de petróleo. Os investimentos da empresa estatal provocaram um incremento considerável da renda gerada no estado. Em 1959, os investimentos da Petrobrás na exploração e refino do petróleo foram equivalentes a mais da metade do PIB industrial da Bahia. A partir do final da década de 50, a indústria química já tinha se tornado uma importante força econômica no estado.

Em 1967, foi criado o Centro Industrial de Aratu (CIA), um complexo industrial multissetorial, localizado nos municípios de Simões Filho e Candeias. O CIA se consolidou como um polo de crescimento industrial com empreendimentos nos segmentos químico, metal-mecânico, de minerais não metálicos, plásticos, fertilizantes, entre outros. Quando a década de 60 chegou ao fim, a Bahia já tinha entrado em um processo de industrialização sem volta e que se acentuaria ainda mais na década de 70, principalmente com a criação do Complexo Petroquímico de Camaçari (COPEC), em 1978. Como afirma o economista Gustavo Pessoti "foi, justamente, na época em que vigorava o regime militar brasileiro, o período de maior industrialização da Bahia"3. Entretanto, essa industrialização e desenvolvimento no estado não se traduziu em uma busca pela equidade e como consequência se ampliou a desigualdade social, o crescimento desordenado da capital do estado e o aumento da pobreza.

A cidade de Salvador, capital do Estado e sede da arquidiocese, sofria com o inchaço da metrópole devido a vinda de pessoas de todo o estado para a cidade como denunciou os documentos da Igreja baiana. O plano pastoral de conjunto da Arquidiocese, de 1967, alertava: "Salvador, onde se desenvolve, nos últimos 25 anos, um enorme desordenado crescimento demográfico". Segundo o documento, o Censo de 1940 registrava uma população de um pouco mais de 290 mil pessoas na cidade, enquanto para o ano de 1960 já tinha ultrapassado 650 mil pessoas. Ou seja, em 20 anos a população mais que dobrou. Como consequência direta desse crescimento desordenado, na década de 1970, as invasões se tornaram um grande problema social da capital, tanto pelos desastres (enchentes, deslizamentos, incêndios etc. (...) que matavam os moradores; quanto pela truculência do Estado em usar a força bruta para desalojar quem morava nestas invasões). Esta era a outra face do desenvolvimento da capital.

Desde a queda do governo do presidente-ditador Getúlio Vargas, em 1945, o Brasil vivia uma democracia que teve sua estabilidade atacada a partir da década de 1960. Foi um momento de extrema politização e polarização na sociedade. Várias manifestações sociais foram promovidas por trabalhadores urbanos e rurais, estudantes e subalternos das Forças Armadas. Aparecia no cenário político, como nunca antes na história do Brasil, a participação de amplos setores populares organizados na defesa de seus interesses. Porém, amplos setores da sociedade se viram ameaçados: os grandes empresários, os setores ligados as multinacionais, setores significativos das camadas médias, oficiais das Forças Armadas e a maior parte da grande Imprensa.

O cenário político nacional se alterou dramaticamente em 31 de março de 1964. Os militares começaram o movimento que derrubaria o presidente da República, João Goulart,

\footnotetext{
3 PESSOTI, Gustavo Casseb. "As Políticas de atração de Investimentos Industriais e o Desenvolvimento Industrial da Bahia no Período do Regime Militar Brasileiro”. In: ZACHARIADHES, Grimaldo Carneiro (org). Ditadura Militar na Babia: Histórias de autoritarismo, conciliação e resistência. Volume 2. Salvador: EDUFBA, 2014, p.151.
} 
que acabaria se exilando no Uruguai e instalaria uma ditadura que permaneceria 21 anos no poder. Logo após o Golpe militar começou uma violenta repressão aos setores da esquerda. A sede da União Nacional dos Estudantes (UNE) foi queimada, universidades invadidas e integrantes das Ligas camponesas, da Ação Popular e do Comando Geral dos Trabalhadores (CGT) perseguidos e presos, além da cassação dos direitos políticos por 10 anos de várias pessoas. A repressão, no contexto baiano, do pós-Golpe, também foi intensa. A residência universitária da Universidade da Bahia foi invadida e 45 estudantes e 2 funcionários presos. A sede do Jornal da Babia também foi invadida e matérias do periódico que sairia naquele dia foram censuradas. A sede do Sindicato dos petroleiros SINDIPETRO foi tomada por forças combinadas da Polícia militar e do Exército. ${ }^{4}$ Os prefeitos das cidades de Salvador, Vitória da Conquista, Ilhéus e Feira de Santana foram depostos. A Ditadura se consolidava no país procurando esmagar as oposições.

\section{Eugênio e a Modernização da Arquidiocese}

Os anos de 50 e 60 do século XX foram um período de transformações profundas na sociedade brasileira. No entanto, a Arquidiocese de Salvador não estava preparada para lidar com as mudanças que o país e o estado estavam passando. A Arquidiocese precisava se atualizar para reagir a esta nova realidade. Até o começo da década de 60, a Sé primacial do Brasil tinha perdido seu dinamismo e sua força de liderança. $\mathrm{Na}$ década de 50 , um momento de grandes transformações na Igreja Católica brasileira, em especial no Nordeste, onde várias inovações foram testadas, a velha arquidiocese estava fechada em si mesma, com pouca relevância nacional. Governada por um Cardeal integrista e reacionário, D. Augusto Álvaro da Silva, conhecido como Cardeal da Silva, era incapaz de oferecer soluções aos problemas que surgiam.

Dom Augusto nasceu, em 1876, em Recife. Em 1911, foi elevado a Bispo da diocese de Floresta, no interior de Pernambuco. Em 1915, foi transferido para a diocese de Barra do Rio Grande, interior da Bahia. Em 21 de maio de 1925, tomava posse da Arquidiocese Primacial de Salvador. D. Augusto foi o grande responsável pelo projeto de Restauração Católica na Bahia nas décadas de 30 e 40 procurando fortalecer o poder da Igreja na

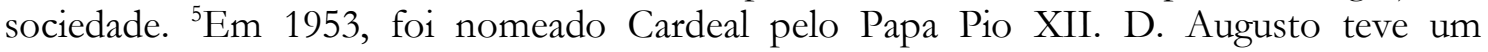
período longo na frente do arcebispado de Salvador permanecendo no cargo por 43 anos, de 1925 até 1968, ano do seu falecimento. ${ }^{6}$

O velho arcebispo não conseguiu acompanhar as rápidas mudanças que a sociedade brasileira passou a partir do pós-II ${ }^{a}$ Guerra mundial. D. Augusto posicionou-se como um antimodernista e figura reacionária, preso em uma arquidiocese que tinha ficado no tempo. Como observou o arcebispo D. Eugênio Sales, D. Augusto "era outra mentalidade (...) quando ele foi nomeado bispo da Bahia eu tinha 4 anos de idade ". ${ }^{7}$ O Cardeal da Silva não

\footnotetext{
4 ZACHARIADLHES, Grimaldo Carneiro. Os jesuitas e o apostolado social durante a ditadura militar - Atuação do CEAS. Salvador: EDUFBA, 2010, p.

5 ALVES, Solange de Santana. A Igreja Católica na Babia: fé e política. Dissertação (Mestrado em História) UFBA, Salvador, 2003

${ }^{6}$ Até então na tradição da Igreja Católica, os bispos governavam a sua diocese até a morte, transferência para outra diocese ou renúncia. Com isso, era comum, que as dioceses ficassem sob a direção de bispos idosos e com problemas de saúde devido a idade, sendo necessário chamar administradores apostólicos para auxiliálos. Em 1966, o Papa Paulo VI promulgou o Motu Próprio Ecclesiae Sanctae estabelecendo a idade limite de 75 anos para o pedido de renúncia dos bispos de suas dioceses, norma confirmada depois pelo Código de Direito Canônico. http://w2.vatican.va/content/paul-vi/la/motu proprio/documents/hf p-vi motuproprio 19660806 ecclesiae-sanctae.html Acesso em 13-11-2016

${ }^{7}$ Entrevista com Dom Eugênio de Araújo Sales, 22-06-2009
} 
acompanhava e nem estimulava as inovações que ocorriam no Brasil durante a década de 50. A despeito de iniciativas importantes realizadas em sua arquidiocese, principalmente por membros das Ordens Religiosas, elas não encontravam eco na principal liderança da Igreja baiana. Apesar de ser Cardeal sua importância se apequenava a nível nacional e isto se refletia na sua quase nula participação na CNBB, principal organização dos bispos no Brasil, fundada em 1952. ${ }^{8}$

Durante a década de 60 , período em que importantes dioceses do Nordeste se abriram a questão social tentando estimular as classes populares na defesa de seus direitos, D. Augusto tomava posições extremamente conservadoras, preocupado com a emergência dos trabalhadores. Ele se tornou um anticomunista virulento. Em uma carta ele avisava que se o "comunismo internacional" tomasse o poder: "assassinará sacerdotes, incendiará igrejas, arrasará conventos, violará religiosas, fuzilará líderes católicos", e ainda, "confiscará propriedades, ferirá, matará, martirizará com requintes de barbaridade e fereza bestial”. ${ }^{9} \mathrm{O}$ Cardeal da Silva deu apoio integral ao Golpe Militar de 1964 que ele defendia desde pelo menos 1963.

Sua dificuldade em se adequar à nova realidade que se abria ficou clara no Concílio Ecumênico Vaticano II. Ele esperava que o Concílio fortalecesse as posições tradicionais da Igreja e condenasse veementemente o comunismo. ${ }^{10} \mathrm{D}$. Augusto só compareceu à primeira sessão do Concílio, não participando mais por discordar dos caminhos que ele estava tomando. Como afirmou um dos padres mais importantes da arquidiocese de Salvador na segunda metade do século XX: "Ele não aceitou as inovações do Concílio Vaticano II". ${ }^{11}$

Em virtude de sua idade e saúde debilitada, em 1964, D. Eugênio de Araújo Sales foi indicado para ser administrador apostólico sede plena da arquidiocese de Salvador pelo Papa. D. Augusto continuava com as honras de Cardeal, mas D. Eugênio Sales era quem governava a Igreja baiana a partir daquele momento. D. Eugênio tinha sido arcebispo de Natal, arquidiocese na qual foi responsável por importantes inovações pastorais e sociais. Ao chegar em Salvador começou a trabalhar de forma acelerada, tinha como missão modernizar e reestruturar a arquidiocese de Salvador, além de aplicar a atualização pastoral do Concílio Vaticano II. Monsenhor Gaspar Sadock que foi vigário geral de D. Eugênio Sales afirma que ele foi o responsável pela "nova arquidiocese" que se estruturou a partir da década de 60: "D. Eugênio foi a pessoa que mais bem fez para esta arquidiocese durante um período muito curto de 7 anos, foi o que menos durou enquanto ao tempo e o que mais bem fez a arquidiocese"

A Arquidiocese de Salvador cobria uma vasta extensão de terra. Em agosto de 1964, o seu território compreendia $57.000 \mathrm{~km}^{2}$, incluindo dezenas de municípios, tendo a capital Salvador como sede. Um problema que era presente em quase toda a Igreja Católica no Brasil, a falta de padres, na arquidiocese de Salvador era muito mais alarmante: "É a Bahia o Estado que se encontra numa situação mais deficitária no tocante ao clero (...) acrescente ainda que é o Estado que possui maior número de clero idoso". Segundo esse documento,

\footnotetext{
8 AZZI, Riolando. A Sé Primacial de Salvador: Igreja Católica na Babia (1551-2001). Período Imperial e Republicano. Vol. II. Petrópolis, RJ: Vozes, 2001, p.509.

9 D. Augusto Álvaro DA SILVA, “Carta Pastoral do Primaz do Brasil”, Vozes n 1, janeiro de 1964, p.65.

${ }^{10}$ Em um texto publicado na Revista Eclesiástica Brasileira, o Cardeal reclama que o Concílio se destinava "em renovar em toda a Igreja o espírito cristão, e assim dar vida e salvação ao mundo", quando na verdade o que se precisava era acabar com a "heresia universal" do comunismo "ateu, imoral, sanguinário". REB, setembro de 1963, p.786-787.

${ }^{11}$ Entrevista com Monsenhor Gaspar Sadock 10-06-2008

12 Entrevista com Monsenhor Gaspar Sadock 10-06-2008
} 
das 79 paróquias 29 não estavam providas de sacerdotes. Existiam 63 padres diocesanos, desses, apenas 5 na faixa etária de 30 anos, enquanto 15 acima de 61 anos. A arquidiocese de Salvador possuía um clero envelhecido. ${ }^{13}$ Esses fatos inviabilizavam o funcionamento adequado da arquidiocese. D. Eugênio procurou resolver esse problema atuando em três frentes.

Aproveitando a conjuntura internacional da Igreja Católica, D. Eugênio conseguiu trazer vários padres estrangeiros para arquidiocese de Salvador para suprir a carência de sacerdotes. Os Papas Pio XII (1939-1958) e João XXIII (1958-1963) já tinham apelado à Igreja europeia que apoiasse a América Latina e a África enviando padres para suprir a carência que existia neste continente. Principalmente depois da Revolução Cubana, essa ação se intensificou para a Igreja latino-americana e o Brasil recebeu vários sacerdotes vindo da Europa e da América do Norte. D. Eugênio através de boas relações que mantinha com a Igreja europeia trouxe dezenas de padres europeus para sua arquidiocese.

Outra resolução de D. Eugênio, sui generis, foi a entrega de paróquias ao encargo de comunidades religiosas femininas. Ele já tinha feito essa experiência pioneira enquanto bispo de Natal, em 1961, quando entregou a paróquia de Nísia Floresta à comunidade das irmãs missionárias de Jesus Crucificado. Em Salvador, depois de conseguir a autorização do Papa Paulo VI, ele deu continuidade a esse projeto, deixando várias paróquias aos cuidados das religiosas. Elas administravam as paróquias, sacramentos e até os cultos, apenas não davam os sacramentos exclusivos dos padres. Como bem recordou D. Eugênio essa parceria com as religiosas: "Funcionou muito bem". ${ }^{14}$ De fato, essa experiência iniciada pelo bispo foi de suma importância, a partir de então, possibilitou uma maior participação das irmãs e freiras nas ações da arquidiocese. Um dos frutos desse momento foi a criação do GRIMPO - Grupo de Religiosas Inseridas no Meio Popular, em 1965, em Salvador, que atua na arquidiocese há mais de 50 anos. ${ }^{15}$

Seguindo as orientações abertas pelo Concilio Vaticano II, D. Eugênio, foi um dos primeiros bispos brasileiros a restaurar o Diaconato permanente na arquidiocese e fundou a Escola Diaconal Arquidiocesana, em 1966. Porém, os resultados não foram tão bons como planejado e o número de candidatos ao diaconato foi aquém do esperado inicialmente: "motivado em parte pela falta de laicato autêntico e pelo desconhecimento da missão diaconal e trabalho de recrutamento de candidatos ao diaconato está bastante difícil". ${ }^{16}$

Devido ao aumento acelerado da população na arquidiocese, ela foi reorganizada territorialmente para melhorar o atendimento religioso, dividida em zonais e criadas 17 novas paróquias. Em acordos com Igreja da Alemanha, D. Eugênio Sales adquiriu carros para as paróquias e assim os padres puderam se locomover mais facilmente. Ele construiu novos edifícios como os Centro de Treinamento de Líderes (CTL) de Itapuã e de Itaparica

13 Arquidiocese de Salvador Atividades desenvolvidas em 1965 e Plano de Pastoral de Conjunto para 1966. (Arquivo do Seminário Central São João Maria Vianney)

${ }^{14}$ Entrevista com Dom Eugênio de Araújo Sales, 22-06-2009

15 Esta atuação pioneira de D. Eugênio Sales na relação com as freiras e irmãs é um aspecto pouco falado da biografia do arcebispo. Em um momento em que a participação mais decisiva da mulher dentro da Igreja ainda era pouco debatida, D. Eugênio já se atentava para isso. Salvo engano, ele foi o único bispo brasileiro que propôs no Concílio Vaticano II a incorporação mais decisiva das mulheres na Igreja: “Antes de tudo, é necessário que nós consideremos a vida religiosa feminina como uma realidade do tempo presente, e com exigências próprias dessa época. De fato, a promoção da mulher é um dos principais sinais dos tempos modernos (...) Por conseguinte, quando se fala de religiosos, deve-se necessariamente falar das mulheres religiosas" (Apud AZZI, Riolando. A Sé Primacial de Salvador: Igreja Católica na Babia (1551-2001). Período Imperial e Republicano. Vol. II. Petrópolis, RJ: Vozes, 2001, p.515-517).

16 Plano de Pastoral de Conjunto da Arquidiocese de Salvador - 1967. (Arquivo do Seminário Central São João Maria Vianney) 
para reuniões do clero e capacitação de leigos. Fundou também o Instituto de Desenvolvimento Integral (IDI) na Universidade Católica do Salvador com o intuito de assessorar a arquidiocese nos problemas sociais.

A promoção do ecumenismo era outra possibilidade aberta pelo Concílio que em seu Plano Pastoral o governo da arquidiocese afirmava que iria tentar promover. Mas, de antemão, o arcebispo sabia das dificuldades que encontraria: "A ação ecumênica já delicada por sua natureza, exige muita prudência entre nós. A falta de experiência do pessoal formado e de consciência ecumênica não só da parte do povo como do clero, faz ressaltar essa exigência". ${ }^{17}$ Dois anos depois ainda era verificada a resistência por parte dos membros da Igreja: "Verifica-se (...) que muitos sacerdotes, religiosos e leigos ainda não acordaram para a importância da ação ecumênica". ${ }^{18}$

Pelo seu trabalho realizado de modernização da arquidiocese de Salvador, D. Eugênio angariava prestígio e força dentro da burocracia católica. Seu trabalho na arquidiocese foi rapidamente recompensado pela Cúria Romana. Ele foi nomeado arcebispo de Salvador, em 24 de outubro de 1968, logo após a morte de D. Augusto. Apenas alguns meses depois foi eleito Cardeal pelo Papa Paulo VI, em 28 de março de 1969. Essa ascensão meteórica de D. Eugênio na hierarquia da Igreja Católica e o seu êxito na reestruturação da arquidiocese não ofuscam os problemas que teve nesse período na Bahia, os quais prejudicaram sua liderança dentro da sua própria arquidiocese.

\section{Eugênio Sales e os conflitos internos}

O arcebispo D. Eugênio mantinha um bom relacionamento com o governo Estadual e com os militares. Também se relacionava bem com as elites do estado, mas não era um bom interlocutor com o resto da sociedade. O arcebispo não procurou dialogar com os vários setores da Igreja Católica baiana. Ele era visto como um homem autoritário por muitos sacerdotes e leigos, além de um aliado da Ditadura. Por algumas atitudes por ele tomadas sua imagem pública era de um conservador e não de um modernizador.

A partir da década de 1960, setores minoritários, mas relevantes politicamente inovaram nas práticas pastorais na arquidiocese de Salvador. Muitos sacerdotes e religiosas tentaram adaptar as diretrizes do Concílio Vaticano II à realidade arquidiocesana, procurando ter novas práticas pastorais e isso causou alguns embates dentro da diocese. Ironicamente, D. Eugênio, que pretendia estimular a atualização pastoral do Vaticano II, interviu para frear essas inovações.

Em 1965, tinha sido eleito como abade do Mosteiro de São Bento, D. Timóteo Amoroso Lima, primo do intelectual católico Alceu Amoroso Lima. O Mosteiro, localizado na avenida 7 de setembro, próximo à Praça municipal, era um dos principais templos católicos da Capital, onde a elite baiana assistia aos seus cultos. O próprio D. Eugênio convidou o Abade para colaborar com o estudo da aculturação da liturgia católica à realidade baiana. Este religioso liderou o movimento de inovação apostólica na arquidiocese e foi um dos principais opositores ao Regime Militar no estado se tornando o ponto de referência das esquerdas, uma figura pública de grande respeito na sociedade baiana.

\footnotetext{
17 Plano de Pastoral de Conjunto da Arquidiocese de Salvador - 1967. (Arquivo do Seminário Central São João Maria Vianney).

18 Plano de Pastoral de Conjunto da Arquidiocese de Salvador - 1969. (Arquivo do Seminário Central São João Maria Vianney).
} 
D. Timóteo Amoroso foi um dos pioneiros do diálogo com o candomblé na Bahia. Em 11 de dezembro de 1965, três dias após o encerramento do Concílio, celebrou no Mosteiro, a Missa do Morro. Nessa celebração foi introduzindo cânticos e instrumentos do candomblé como os atabaques, berimbaus e agogôs. Com a Missa do Morro, ele procurou introduzir uma renovação litúrgica que buscava sua aculturação com as raízes africanas da Bahia. Entretanto, essa celebração causou uma grande reação negativa por parte significativa dos leigos e resistência do clero mais conservador. Os jornais baianos repercutiam as indignações de espanto de muitos: "Fechando os olhos, eu tinha a impressão de encontrarme no meio de uma floresta africana, ou num terreiro de candomblé, ouvindo as lamentações dos oguns" ${ }^{\prime 1}$.

Quando ocorreu a missa, D. Eugênio estava em Roma. Assim que retornou foi falar muito irritado com o abade. Como confirmou na entrevista que me concedeu, ele proibiu que D. Timóteo voltasse a fazer outra missa como aquela, que já estava programada para acontecer. Ele lembrava que o Mosteiro era autônomo da arquidiocese, mas não poderia ir de encontro às normas do arcebispo. ${ }^{20}$ Um monge que assistiu a conversa de D. Eugênio com D. Timóteo afirmou que ele foi muito duro com o abade, demonstrando estar muito irritado. ${ }^{21}$ Muito do problema de D. Eugênio era do fato dele não ter sido consultado e principalmente pela repercussão negativa que a Missa gerou na sociedade baiana. Para Monsenhor Gaspar Sadock: "Embora ele [D. Eugênio] fosse um inovador, o abade era mais inovador do que ele. (...) D. Eugênio achou que a Bahia não estava preparada para a Missa do Morro". ${ }^{22}$

Em 1966, devido a confrontos políticos entre o episcopado e os estudantes católicos, em especial os universitários, a CNBB extinguiu a Juventude Universitária Católica (JUC), a Juventude Estudantil Católica (JEC) e a juventude Independente Católica (JIC), importantes vertentes da Ação Católica que influenciaram a esquerda católica durante as décadas de 50 e 60. D. Eugênio Sales mostrou toda sua impaciência e discordância com o movimento. O arcebispo marcou uma reunião com os membros para informar o fim da entidade. Os integrantes quiseram argumentar, mas D. Eugênio não aceitou dialogar e quando o jovem Haroldo Lima ia falar, o arcebispo levantou-se, saiu e bateu a porta sem ouvi-lo. Atitudes como esta faziam com que ele fosse visto como um bispo autoritário e insensível pelos setores católicos mais à esquerda. ${ }^{23}$

Até setores moderados da Igreja Católica tinham dificuldade em trabalhar com D. Eugênio. A intelectual católica Yvette Amaral, originária da Ação Católica da década de 50, que tinha uma participação muito ativa dentro da Igreja baiana escrevendo regularmente para os periódicos da arquidiocese, confirmou a dificuldade em trabalhar com a forma centralizadora de D. Eugênio governar. ${ }^{24}$ Já Cândido da Costa e Silva, na época padre na arquidiocese, não sentia apoio, nem segurança no arcebispo para desenvolver nenhum trabalho naquele momento histórico. ${ }^{25}$ Pela sua forma de trabalhar D. Eugênio, por mais que quisesse, não conseguia mobilizar o laicato para desempenhar atividades mais decisivas para arquidiocese: "Assim não existe nada, ou quase nada, para a mobilização do laicato, a

\footnotetext{
19 A Tarde 21 de dezembro de 1965

${ }^{20}$ Entrevista com Dom Eugênio de Araújo Sales, 22-06-2009

${ }^{21}$ Entrevista com D. Bernardo Lucas 29-10-08

22 Entrevista com Monsenhor Gaspar Sadock 10-06-2008

23 Entrevista com Luis Antonio Amorim de Aguiar (25-11-06), Anete Bernardes (16-01-10), Emanuel

Bernardes(16-01-10), Solange Silvany Lima (19-01-11) e Joviniano Carvalho Neto (24-10-06)

${ }^{24}$ Entrevista com Yvette Amaral (10-10-08)

${ }^{25}$ Entrevista com Cândido da Costa e Silva (27-07-09)
} 
não ser para os das classes mais altas; e os seus programas sociais, muito estruturados, são sustentados pelo Governo", ${ }^{26}$

D. Eugênio Sales teve problemas sérios com alguns padres estrangeiros que ele tinha chamado para integrar a arquidiocese. Dentre os padres estrangeiros, ele entrou em confronto, em especial, com 4 padres franceses que se reuniam na Igreja do Pilar, próximo ao bairro histórico do Pelourinho: Os padres Camile Roland, Alfred Hervegruier, Jean Lacrevaz e Pierre Demoulier. Esses sacerdotes assumiram responsabilidades nas paróquias e na assistência à organização da Ação Católica. Eles trabalhavam com as classes populares e faziam oposição aos militares. Estes sacerdotes não aceitavam a posição que o arcebispo mantinha com os militares, a quem para eles, e para muitos outros, D. Eugênio era cúmplice do que ocorria. Principalmente depois da expulsão do padre Camile. ${ }^{27}$

O Padre Camile Roland era pároco no bairro de São Gonçalo do Retiro e assistente da ACO - Ação Católica Operária. O sacerdote fazia trabalho de organização com os estivadores. Ele organizava reuniões com opositores do Regime, publicava documentos denunciando a Ditadura e fazia crítica aos militares inclusive nas missas que pregava. No dia 28 de julho de 1969, a Polícia Federal chegou a detê-lo por três horas. ${ }^{28}$ Dom Eugênio intercedeu por ele junto à Polícia e o sacerdote ficou no palácio arquiepiscopal por alguns dias até que fosse resolvida a questão. Nos acordos entre o arcebispo e os militares ficou decidido que ele não seria preso, mas deveria retornar a França. Como confirmou D. Eugênio, o padre ficou muito chateado com ele quando soube da notícia, pois achava que D. Eugênio deveria defendê-lo e com essa atitude ele estava capitulando. O padre Camilo voltou para a França, em 26 de setembro de 1969, D. Eugênio fez questão de levá-lo para o aeroporto pessoalmente em seu carro. ${ }^{29}$

Outro problema do arcebispo com um padre francês foi com Pierre Demolièrre, um padreoperário que ajudou na fundação da Associação Profissional dos Trabalhadores da Indústria Petroquímica - ASPETRO. D. Eugênio, um dia, mandou chamar o padre para que fosse informado que ele seria enviado para uma paróquia distante da capital, próximo ao estado de Sergipe, e que estava proibido de continuar trabalhando nas fábricas. Ele quis saber o porquê dessa decisão do arcebispo, e foi informado a ele que foi devido acordos com os militares. O padre Pierre mandou um recado a D. Eugênio de "que suas decisões eram políticas, as dele eram religiosas" e por isso não aceitaria as suas ordens. Então, D. Eugênio o proibiu de ministrar qualquer ofício religioso e ter contato oficial com a Arquidiocese. Na prática, como ele devia obediência no Brasil ao arcebispo de Salvador, ele não poderia exercer mais a função de padre no país. ${ }^{30}$

\footnotetext{
26 BRUNEAU, Thomas. O Catolicismo brasileiro em época de transição. São Paulo: Editora Loyola, 1974, p. 312.

27 Pelo menos dois destes sacerdotes, em graus variáveis, tiveram contato com a esquerda armada na Bahia. Mas, isso não foi o motivo da repressão chegar até eles, pois os militares não sabiam desse fato como pode ser comprovado no processo de expulsão do padre Camilo Roland que em momento algum esse contato foi alentado pela repressão. Inquérito Camilo Antonin Roland.Expulsão Babia. Ministério da Justiça. 21-07-1969. (Arquivo Nacional)

28 CARTA ABERTA AO PE. CAMILO ROLAND (a propósito de sua saída do Brasil a 26/09/69). (Arquivo Particular de Cândido da Costa e Silva).

${ }^{29} \mathrm{Na}$ memória dos militantes este transporte do padre Camilo pelo arcebispo em seu próprio carro até o aeroporto foi uma prova da sua capitulação aos militares já que era uma forma dele se assegurar que o padre iria embora. Na versão de Dom Eugênio na entrevista que me concedeu, foi que, mesmo sem o sacerdote querer a sua carona para o aeroporto, ele assim o fez, para ter certeza que ele não seria preso pelos militares no trajeto até o aeroporto.

30 Entrevista com Pierre Demolierre (17-12-08). Também ver a autobiografia de Pierre Demolierre "O submisso liberta-se”. Edição do autor, s/d.
} 
Naquele período de radicalismo, as atitudes de D. Eugênio minavam a sua autoridade arcebispo perante setores católicos de esquerda e outros setores da sociedade. Ele era visto como um aliado da Ditadura. O ex-militante e jornalista Emiliano José afirma que "dom Eugênio chegou a admitir que a tortura era um 'mal necessário" (JOSÉ, 2002, p.205). Apesar dessa acusação ser inconsistente, já que não é apresentada nenhuma prova disso; esta afirmação, mais do que um fato, demonstra a visão que o arcebispo da Bahia tinha para os setores das esquerdas.

D. Eugênio de Araújo Sales não era um simples fantoche da Ditadura. Ele fazia críticas contundentes ao Regime nos bastidores, inclusive em relação a violação dos direitos humanos. Quando da promulgação do Ato Institucional n ${ }^{\circ} 5$, que radicalizou a repressão, o general responsável pela área da arquidiocese pediu a D. Eugênio que celebrasse uma missa em louvor a nova ordem, o arcebispo foi enfático na sua resposta: "Vocês que estão contentes com o AI-5 podem agradecer a Deus, mas não por meu intermédio". ${ }^{31}$

Em protesto contra a prisão de um padre, D. Eugênio proibiu a celebração de uma missa em ação de graças pela "Revolução" e se recusou a receber uma medalha do Regime Militar. Ele apoiou os beneditinos, em Salvador, quando tiveram problemas com a repressão. Ele interferiu em favor do monge D. Jeronimo Sá Cavalcanti quando soube que ele poderia ser preso. Quando o Mosteiro de São Bento foi invadido pela polícia Militar, em 1968, ele foi até o Mosteiro prestar solidariedade ao abade. ${ }^{32}$

Entretanto, estas atitudes eram eclipsadas pelas suas aparições ao lado dos militares e o bom trânsito que ele mantinha com o Governo. D. Eugênio pouco intercedia em favor dos estudantes, trabalhadores e presos políticos. Apesar dele se preocupar com o aumento da repressão dos militares no pós-AI-5, em poucas vezes, ele utilizou de sua autoridade para intervir em prol dos perseguidos. Em uma ocasião, ele chegou a interceder em favor do estudante Renato Affonso que tinha sido preso e que estava sendo torturado pela polícia pelas ligações que ele mantinha com a família do rapaz. ${ }^{33}$

Seu estilo autoritário de governar e de tentar impor sua autoridade criava obstáculos para D. Eugênio Sales dentro da sua arquidiocese. As boas relações que ele mantinha com a Ditadura, fez com que o arcebispo tentasse controlar os setores católicos que se opunham aos militares. O conflito com o arcebispo foi inevitável. As afrontas que D. Eugênio começou a sofrer demonstra a deterioração de sua autoridade moral perante setores da Igreja Católica baiana.

Padres e leigos começaram a distribuir cartas apócrifas atacando D. Eugênio nas igrejas, casas dos párocos e leigos denunciando a omissão ou conivência do arcebispo naquele momento com a Ditadura. Era uma forma de atacar o Cardeal. D. Eugênio lembrava de ter recebido uma carta dessas no dia do seu aniversário em sua residência. ${ }^{34}$

Essas cartas começaram a ser distribuídas a partir de 1968 e continuaram até a saída dele da arquidiocese de Salvador. Uma dessas missivas que foram distribuídas pela diocese aborda um Congresso Eucarístico promovido pela Igreja Católica, em 1970, em Salvador e que teria a participação dos militares. Esta carta dá uma dimensão dos ataques que o Cardeal sofria naquele momento:

\footnotetext{
31 Elio Gaspari, “Um Sacerdote de intransigência”. Jornal O Globo, 01/10/1997

32 Estas atitudes do arcebispo eram vistas por vários setores apenas como uma proteção à instituição católica, em função do esprit de corps, e não como uma preocupação com a dignidade humana como fica claro na percepção de Cândido da Costa e Silva: "Para Dom Eugênio a instituição é mais importante que o homem". Entrevista com Cândido da Costa e Silva (27-07-09)

33 http://www.emilianojose.com.br/a-premonicao-de-yaia/. Acesso em 14/01/2016

34 Entrevista com Dom Eugênio de Araújo Sales, 22-06-2009
} 
"Ao Cardeal Arcebispo,

Aos padres, religiosos e religiosas e leigos da Arquidiocese (...)

Podemos ficar satisfeitos das homenagens que serão prestadas ao Cristo Eucaristia e ao legado Pontifício, sabendo que o Governo está prestigiando e quase patrocinando tudo isso e fará tudo para que apareça sempre mais a união da cruz e da espada, a espada para defender os "valores cristãos" do nosso povo, a cruz para cobrir a ditadura militar?

O mesmo governo que prestigia a religião, mantém nas prisões muitos padres e leigos, réus só por ter tomado ao pé da letra as palavras do Cristo "tudo que fizerdes ao menor dos meus irmãos, é a mim que o fizestes", réus por querer um futuro melhor para o povo.

Como pode Dom Eugênio, Legado Pontifício, ter a coragem de celebrar a Eucaristia, sinal de união, cercado por militares, quando Cristo está padecendo nas cadeias, está sendo torturado por estes mesmos? (...)

O nosso Cardeal Arcebispo, Legado do Papa ao Congresso, declarou que as torturas de presos políticos são casos isolados e que isto não acontece normalmente. Nós sabemos que Dom Eugênio foi informado dos pormenores do que acontece nas cadeias do nosso país; por que ele quer amenizar a gravidade dos acontecimentos? Será que ele prefere negar a verdade por amor de "tranquilidade"? Mas, Cristo não veio para trazer a paz, mas a espada... (...)

Estamos cheio de tristeza em comunicar-lhes estas nossas reflexões mas sentimos que não podemos mais calar.

Queríamos assinar esta carta, mas os senhores sabem que na situação atual seria risco demais.

Gostaríamos que refletissem sobre estas nossas reflexões e preocupações.

Unidos no mesmo amor ao Cristo Eucaristia e ao Cristo vivo no povo

Salvador, 13 de maio de 1970

Um grupo de leigos de Salvador." 35

A repercussão das cartas extrapolou as fronteiras da diocese. D. Expedito Oliveira, bispo de Patos, na Paraíba, que tinha sido colega de seminário de D. Eugênio, veio em defesa do arcebispo afirmando que ele com "alto domínio sobre si mesmo (...) enfrentou forte onda de oposição da parte de um anônimo que procurou deslustrar sua atuação em Salvador". ${ }^{36}$ $\mathrm{Na}$ entrevista que me concedeu D. Eugênio Sales tentou passar a imagem de que as cartas não o incomodaram tanto. Pode até ser que depois de décadas do acontecimento, ele se sentisse dessa forma. Entretanto, em 1976, quando já não era mais arcebispo de Salvador, D. Eugênio foi convidado pelo então arcebispo D. Avelar Brandão para as comemorações do tricentenário da Arquidiocese de Salvador, D. Eugênio condicionou a sua ida apenas se o "o das cartas anônimas" não tivesse posição de destaque no evento, sem relatar o nome de quem seria. D. Avelar respondeu que ninguém "do grupo suspeito" que provocou "sofrimento moral" a D. Eugênio estaria na comissão Executiva do Evento. ${ }^{37}$

\footnotetext{
35 Carta Aberta ao Cardeal Arcebispo, aos padres, religiosos e religiosas e leigos da Arquidiocese. 13-05-70. (Arquivo pessoal de Cândido da Costa e Silva).

36 “Cardeal Eugênio Sales". D. Expedito de Oliveira. Sem Data provavelmente ano de 1969. (LEV/UCSAL).

37 Carta de D. Eugênio a D. Avelar 19-05-1976 e Carta de D. Avelar a D. Eugênio 9-06-1976. Classificador Tricentenário Correspondência. (LEV/UCSAL).
} 
No dia 13 de março de 1971, o Papa Paulo VI nomeou D. Eugênio Sales Arcebispo do Rio de Janeiro devido a sua importância dentro da CNBB e do CELAM, o seu trabalho eficaz de reestruturação da arquidiocese de Salvador, além dos bons contatos políticos que construiu. Contrastando com isso, Dom Eugênio não conseguiu se tornar um líder efetivo dentro da Igreja Católica baiana. Se ele não era um simples joguete nas mãos dos militares e não aprovava a tortura, tampouco se tornou uma figura de destaque na defesa dos direitos humanos no estado. Só interveio em casos de torturas por relações próximas aos envolvidos. Naqueles tempos de repressão, não procurou manter contato com os sindicatos, membros do Movimento Estudantil ou presos políticos. Faltava-lhe carisma e comunicação para chegar às massas. A repressão aos setores progressistas o enfraquecia dentro da Igreja baiana. 